\title{
Ethnicity and Politics: Yugoslav Lessons for Home
}

\section{E. A. Hammel, University of California, Berkeley}

(The article first appeared in Anthropology Today, July, 1997. It is reprinted here by permission.)

Balkan society is a frightening mirror for our own. Here I draw attention away from the usual preoccupation of who did what to whom, toward underlying structural problems in the achievement of a peace that could have been overcome with luck and diplomatic skill. These structural features are characteristic of many regions, and they can be overcome.1

\section{Tribes and History}

The history of Europe and the Near East, like that of other places with deep roots that run to the treetops (thus the Old World but mostly not the New) is a history of local kinship units with rights to land and no way to make a living without it. The idea that participation in social and economic life was possible without access to land was, with few exceptions, unthinkable. As population became more dense (and I imply a very ancient regime like the Neolithic), kinship groups became large enough to be thought of as ethnic groups. While some kinship groups might achieve dominance over others but still remain part of a single ethnic system, claims on loyalty beyond that could no longer depend on the ascribed statuses of kinship but had to be negotiated in terms of the achieved contracts between ethnic groups even if they were sometimes symbolized in kinship usage. This shift is the transition from tribalism to feudalism, and the echo of Henry Maine is unmistakable. As population became still more dense, ethnic dominance became more complex, with one group often achieving dominance over several other ethnic groups. This is the transition from feudalism to imperialism. It is in the dominance of one ethnic group over multiple other ethnic groups that co resided in the same territory or were contiguous within the scope of empire, that the roots of the Yugoslav and similar problems lie. This sketch is intended in no way to be evolutionistic but only historical, and not even uniformly so, frequent but not inevitable. 


\section{Imperial Hegemony}

There are several kinds of imperial domination. In the first, a dominant ethnic group holds sway over several others whose positions, either structurally or geographically, are disjoint. Under such circumstances the level of competition between the subordinate groups can be, although it is not always, low. They are, in ecological terms, allopatric. The solidarity of the subordinate groups is in some sense organic. The distinction between vlasi (shepherds) and meropi (agricultural serfs) in the mediaeval Serbian empire is a case in point; each group had its own economic sphere, and indeed they were forbidden by the Code of Stefan Dusan to intermarry. Caste systems can have this characteristic, as do most hierarchical systems supported by elaborate religious symbolic structures. They drip legitimacy.

In a second type, a dominant ethnic group holds sway over several subordinate groups that are in competition for the same resources. They are, in ecological terms, sympatric. The solidarity of the subordinate groups is in some sense mechanical. Competition between them can not only plauge them and cause trouble for the controlling elite, but can also provide an opportunity to exploit their competition for imperial benefit. Divide et impera is the rule in such a system. The Roman Empire is an example, and others spring readily to mind. If organic solidarity emerges at the level of the subordinate groups, let us say through trade relations, trade flows through the controlling hands of the imperial elite and becomes part of the mechanisms of domination.

In a third type, there is more than one dominant ethnic group, and these dominant groups are themselves in competition. If they do not share subordinate groups, their conflicts are relatively simple to understand. Many imperial clashes have been of this kind, as for example the initial conflicts between the Ottomans and the mediaeval Serbian Empire. But if their competition progresses through expansion and they encroach on one another's territories, they often pass to a fourth type.

In the fourth type there are multiple dominant ethnic groups, and they share one or more subordinate ethnic groups across imperial boundaries. They may do so because one empire has succeeded in wresting territory from another, or because two or more empires have come to dominate parts of one or more subordinate groups, or because members of a subordinate group in one empire have fled to another empire, or for any combination of these reasons. 
As before, this exercise in ideal-typical speculation is not intended to set forth an inevitable succession. History has many variant examples. The situation in the Balkans, along with that in most of the Middle East and in a few other parts of Europe is one of the most difficult. It is especially the tribal and imperial borderlands that give trouble, and in particular the edges of the Germanic expansion, whether north and west against the Celts, south and west against the Latins or, most relevant to this discussion, eastward against the Slavs. The core of the problem lies in the territoriality of subordinate ethnic groups.

\section{Balkan Politics}

For as long as we have records, the Balkans have been an area of conflict between empires. I do not here recapitulate accounts already published,2 save to say that the ethnic identity of groups was in many ways of extrinsic or hierarchical origin, achieved by absolutist definition or the machinations of local elites. Ethnic emergence is not all from the bottom up in some kind of inchoate welling of the spirit, as the romanticist tradition would have it. Little by little, in the flow of empires and the consolidation of local power, political mobilization led to ethnic nation states that purported to have an unbroken existence out of the mists of history. The Paris Peace Conference in 1919 played no small role in solidifying these trends, and ethnography and folklore no small part in symbolizing and legitimizing the new entities, culpa nostra.

The key to the thinking continued to be Neolithic -- that ethnic groups had rights to territory and that territories should be ethnically homogeneous. The mixing of ethnic groups on imperial territories, by flight, by forced relocation, or by opportunistic migration -- all a consequence of imperial conflicts -- created an ethnic chaos incompatible with these territorially neat organizational ideas. Pursuit of the idea of ethnic homogeneity under such circumstances can only result in war, as ethnic chaos is transformed into ordered power.

\section{Other Voices, Other Rooms}

There are of course other solutions. The Communist regime in Yugoslavia after 1945 probably came closer to a long term solution than any other recent empire in the region. It made allegiance to the Party the key to success. It attempted to create and impose a universal church 
that would not only subsume but eliminate competing symbolic systems. It discouraged ethnic chauvinism and was in fact draconian in suppressing it, on the Soviet model. The Achilles' heel of the Communist attempt to replace ethnic identity by political citizenship and secular religion was the continuing penetration of the positions of power and control by Serbs, although that penetration was probably less than it had been under the Serbian monarchy. Resistance to it, not only by the non-Serbian populace but also by non-Serbs within the Party apparatus itself, led to increasingly open interethnic hostility, as Tito's influence waned. Only raw power could hold Yugoslavia together. That power was typically represented by a Serbian official at local levels and became increasingly important within the government itself, especially during the tenure of the Serb, Rankovic, as head of the secret police in the mid-sixties. Tito disenfranchised the minority Serbs outside of Serbia by denying them the special voting privileges accorded nonSerb minorities in Serbia, the Voyvodina, and Kosovo, and such constitutional moves led to deep resentment among the Serbs of the Diaspora. The outcome under these circumstances was division in the Party, collapse of the state, secession by constituent units, and an attempt by the most powerful of them to retain control, especially because its coethnics resided in the secessionist parts. Without stretching the analogy too much, the Titoist independence from Moscow, like Henry VIII's from Rome, was finally overcome by Protestants whose separate identities grew out of the social and economic positions to which they had been allocated by the organs of power. Without stressing another analogy too much, I point out that Tito's moves were a form of affirmative action designed to restore political voice to ethnic groups that had been denied it by previous structures of power. In the end, the call to the ethnic standard was the only viable device left for political mobilization as a multiparty system came into being. Is there a solution besides the traditional application of force, in this or in similar instances? In my musings on this I clearly betray my allegiance to the rationalist notions advanced by Jefferson, Franklin, Paine, and other luminaries of the American Rebellion, my admiration for Gellner's vision of a modern society, and my continuing confusion between Weber's simultaneous celebration of rational decision-making and religious ideology, as against the Marxian insistence on the importance of the relations of production, that is the location of original sin in economic processes.

The first element of an alternative and, to me, just solution is the development of a culture of civil rights and citizenship. It requires abandonment of the notion that polities are 
necessarily territorial and that ethnic groups in particular have rights to territories and thus to constitute homogeneous polities. It means, and it is no news to Marxists, that persons in a civil society should have rights of participation founded on their position in the socioeconomic system rather than on where they live. That goal is not easy to achieve, because all people live somewhere, all somewheres have issues, so that politics cannot help but be local in some important degree. But it is a far cry from worrying about local schools and fire protection to insisting that all issues be determined by locality.

The development of a system of representation under which advocacy can be nonlocal would allow ethnic groups to achieve representation wherever they resided. It is hard to see how to develop such a system in a formal way, because self-conscious interest groups are infinitely divisible (witness, for example, religious cults). We accomplish such representation in the United States in an informal way. We have female candidates, Asian, Black, Hispanic candidates, and so on, and it is up to these politicians to decide how to balance their duties of general representation (on let us say issues of economic policy) against their duties of group representation. The system often does not work well, but it always works better than nothing. Of course, such people must be elected in the first place, and the current mood on the Supreme Court is antipathetic to nonliteral interpretations of the constitutional structure of representation, which is based on locality in a way that was sensible when people had to walk to vote. The Court has struck down attempts to achieve ethnic representation by gerrymandering voting district boundaries. There is some foundation to the cautious attitude of the Court, although their constitutional rationale may not be just the same as the motivations of all the Justices. From all the evidence at hand and especially the Yugoslav, the institutionalization of ethnicity (as opposed to its celebration), by whatever means, prejudicial or restorative, is the road to hell. That road, as we know, is paved with good intentions. It is of course possible for that road to be the best, or the only workable, alternative in a set of dreadful alternatives.

Broader currents of change may also assist. Part of our limited success in containing ethnic conflict in the United States depends on the absence of strong historic ethnic claims to territory; thus far Hispanics have not formally asked to have California and the Southwest back, although they may soon have them de facto, and Native Americans have claimed and received monetary compensation for lost lands. The reason for the paucity of ethnic claims to territory is of course the historical fluidity of the American economy and the force of migrational mixing. A 
clever government that wanted to avoid ethnically based territorial conflict would encourage internal migration. Tax policy has been used for many purposes, why not for this one? The key in the U. S. tax code is the deductibility of moving expenses. The portability of health and retirement benefits that allowed workers to stay in an insurance pool even if they changed jobs and locations would also assist. While problems of ethnic territoriality are not acute across large regions like counties and states in the U.S., they are acute in the cities. It would help to find clever ways to diminish residential ethnic segregation, and the cleverest way is through economic mobility and fair housing legislation. Indeed, it has been shown that the residential segregation of Blacks is now less in Southern cities in which new housing has been built than it is in Northern cities in which the housing stock has been stagnant, simply because the new housing has been built in a period in which ethnic discrimination in the real estate market is illegal. This path to solution only works if Blacks participate enough in the economy to get into the real estate market at all.

Ethnic conflict can still arise, even in the absence of claims to territory, if ethnic groups are allocated to and kept in social positions that have markedly different access to social and economic benefits. A permanent underclass in any society is always a potential source of trouble. If it is ethnically or religiously identifiable, it is a powder keg. Little, if any, of the rhetoric about affirmative action addresses this point; symbolic discourse is seldom about the fundamental issue. "Cultural diversity" can be seen as a code phrase for "Fix it before it blows up." The important issue in the preservation of a polity, as distinct from the preservation of the hegemony of some portion of it, is the prevention of internal conflict. Long term organizational planning must include policies that maximize the migration of ethnic groups not only across territory but also through positions in the social structure, in order to break the easy identification of ethnicity with social position. There has been a great deal of this structural migration of ethnic groups in the United States, unless they were culturally marked in ways that were difficult for the majority to overlook, as for example by skin color.

Yet another kind of mobility is that of cultural and symbolic systems across social groups, which we usually think of as diffusion. Especially under the homogenizing influence of the much-maligned mass media, ethnic groups in many countries share large parts of major symbolic systems. The sports and entertainment industries are cases in point. Football and baseball in the U.S., soccer in other countries, basketball in many, the cinema, and musical forms 
like jazz and rock are great unifiers and diminishers of cultural distance. (It is no wonder that they are viewed with suspicion by totalitarian regimes.) People who compete for jobs and would not intermarry can still talk peaceably about baseball, although to be sure they can also fight about soccer. The importance of commonality in that most essential of all symbolic systems, language, cannot be overlooked. The recent debate about the place of "Ebonics" (lower class Black urban English) in the educational system is a case in point. That speech style, like all local dialects, is seen as an impediment to full participation in social and economic life, but for some, it is a matter of local pride and a particular social role. It should not pass without notice that the speech style of sportscasters on television or the texts of sportswriters in the print media are different from those of the anchors or the editorial writers, both in Britain and the United States. No one misses the symbolic implications of the differences or the effects of speech style on mobility in the job market.

There is another kind of mobility, as well, and that is the mobility of persons across ethnic boundaries. The ultimate blurring of ethnic boundaries comes through intermarriage. A clever government would give tax breaks to married couples who broke ethnic ranks; such a demonstration in support of family values might even tempt a Pat Buchanan. Marriage as an alliance system of course has a long history -- between royal houses, between clans, between localities -- it could not harm interethnic relationships if interethnic marriage were thought acceptable by all parties, and the resultant blurring of original boundaries over the generations would ultimately diminish the problem. It might not eliminate it; for example, even in Brazil where ethnic intermarriage is fairly frequent, darker persons are often allocated lower social positions than lighter ones, despite the proverb that "Money makes white." Similarly, in Yugoslavia where ethnic intermarriage did occur among urban professionals, one of the effects of the recent war has been the breakup of many such unions. I make no naive claim that marriage is a peaceable institution or that it diminishes conflict in some simple way. It just confuses conflict and blurs the fault lines in the larger society.

Finally, we may anticipate some decline in the importance of the ethnic nation state itself. Ethnic nation states may have been a natural form of organization when economies were national, one ethnic group was ascendant, and transportation, especially of bulky goods, was crude, inefficient, and expensive. The national character of economies is disappearing before our eyes. They are no longer local, and even when they are expansionist they are not part of an 
explicit national imperialism, as for example the Dutch or British East India Companies were. They are just after the money, not the glory. Under the pressure of such changes, there is less reason for local elites to be concerned with territories and the control of economic systems located on them. It is more important for such elites to control the international networks and the flow of finance. Further, economic activity cannot be conducted efficiently under hostile conditions, and the emergence of ethnic warfare is detrimental to everyone's economic interests. The economic burden of the so-called civil wars of the late 20th century is enormous, on those directly involved, on the countries who have to pay for the peacekeeping and relief efforts and on the economic players who see their markets go up in smoke. Only the munitions dealers and NGOs delivering services to refugees prosper under these conditions.

\section{Conclusions}

Centuries ago, politicians were persuaded that their greatness depended on the size of their populations, which could be increased most easily by conquest. Beginning perhaps with Adam Smith and Malthus European rulers were convinced that their greatness depended on the extent of their territories, which could also be increased most easily by conquest. Under both philosophies, the growth and collision of empires produced ethnic strife and intensified ethnic identification, which emerged disastrously when imperial control collapsed, and sometimes led to that collapse. Nowadays the instrument of greatness is not conquest but infiltration and control of world markets. While in former times successful conquest may have improved the life chances of even the lowliest of the conquerors, in modern times successful infiltration of other economies may impoverish those at home in elite orgies of downsizing and outsourcing. Some politicians are thus persuaded that their greatness depends on the productivity of their populations, or to coin a phrase, "It's the economy, stupid." These politicians must do three things. First, they must, despite the increasing disjunction between the polity and the economy, strive to focus and contain economic forces within the polity that they represent; else they will represent nothing. Second, they must strive to increase the wealth of that polity by increasing the productivity of its labor force, else they will not be the representatives of their polities for long (even in nondemocratic systems). Third, they must strive to break the links between easily identifiable and traditionally marked social categories (like genders and ethnicities) and 
particular loci in the socioeconomic system (like homeless, unemployed, on the dole, blue collar, rich, and so on), else their polities will fracture before their eyes (and surely before the next election). To succeed, they must maintain at least the same level of general welfare, but they must also strengthen the mechanisms of mobility of persons, symbols, opportunities, and rewards in order to prevent differentiation that can too easily emerge as separatism.

As current acrimonious debate in California regarding the constitutionality of affirmative action currently demonstrates, one of the most difficult things they must do is break the link between gender or ethnicity and economic disadvantage without setting the stage for retaliatory restitution of the status quo ante. While there are some who adhere to the belief that nations, races, and genders have been assigned to their social positions by nature or by God, there are others who cherish a belief in the unconstrained opportunity for individual achievement. They may hold this view for entirely practical and nonideological reasons. For example, because variance exists within groups, natural selection can be expected to work more efficiently at the individual level than at the group level, and society, as a whole is better off if selection is directly for achievement rather than for some presumed and inevitably imperfect correlate thereof. There is no bleeding heart liberal core to that notion, just as there is not to the idea of the necessity of maintaining social order. Nevertheless, what proponents of individualism must decide is whether it is necessary to combat historical and current ethnic and gender discrimination with similarly ethnic- and gender-specific countermeasures, or simply to proscribe it. Especially difficult for them is the problem of sharing a bed with those who would be perfectly content to keep their ethnic- and gender-based historical advantage. But sleeping with the enemy is no new tactic in political reform.

Although my last remarks seem far from the original topic, these apparently disparate subjects, warfare in the Balkans, the election of minority representatives through deliberate adjustment of voting districts, and affirmative action in California, are closely related in a structural sense. Consciousness of group identity, while a powerful force in creating solidarity, is also a powerful force in creating deadly conflict. Such consciousness can arise at any level of social organization. The survival of any such level above another of divisive consciousness depends on intelligent dilution of differences through mechanisms like the mobility of persons or the permeability of symbolic boundaries. A rational polity in the grip of the powerful symbolic forces of ethnicity or religion cannot last, or in the words of Lincoln, "A house divided against 
itself cannot stand." In the long history from Diocletian to the tragedies of modern Bosnia that can be seen from his very doorstep, in Ngorno-Karabakh, Kashmir, Rwanda and Zaire, we see a mirror and lessons for the preservation and improvement of our own imperfect solutions and lucky happenstance. Sadly, nothing we see around us leads us to believe that our politicians have the wit or the will to seize the day.

\section{Notes}

$1 \mathrm{I}$ am indebted to Burton Benedict and Elizabeth Colson for their comments. I have also profited much from the writings of Robert Hayden. None of these is responsible for my views.

2. For a more detailed view of the Yugoslav collapse and ethical dilemmas arising therefrom, see inter alia "The Yugoslav Labyrinth", Anthropology of East Europe Review 11:39-47, Special Issue: War among the Yugoslavs, rev. ed. 1994. (D. Kideckel and J. Halpern, eds.); "Demography and the origins of the Yugoslav civil war", Anthropology Today 9 (1) :4-9) 1993; "Meeting the Minotaur" (Anthropology Newsletter 35 (4): 48, 1994; "Minotaur redux. Anthropology Newsletter 36 (2): 2, 1994; "Science and humanism in anthropology: a view from the Balkan pit", Anthropology Newsletter 36 (7): 52, 1995; Lessons from the Yugoslav labyrinth. In War in ex-Yugoslavia: culture and conflict (D. Kideckel and J. Halpern, eds.). Pennsylvania State University Press, in press. 